\title{
New Spiro-Tin Compounds: Reaction of N,N'-Dialkyl Sulfur Diimides with Cyclic Bis(amino)stannylenes - Unexpected Formation of a N-N Bond
}

\author{
Max Herberhold*, Christian Köhler, Wolfgang Milius, Bernd Wrackmeyer* \\ Laboratorium für Anorganische Chemie, Universität Bayreuth, D-95440 Bayreuth
}

Dedicated to Professor H. W. Roesky on the occasion of his 60 th birthday

Z. Naturforsch. 50 b, 1811-1817(1995); received March 17, 1995

Sulfur Diimides, Bis(amino)stannylenes, Redox Reactions, Spiro-Tin Compounds, X-Ray

$\mathrm{N}, \mathrm{N}^{\prime}$-Dialkyl sulfur diimides (1), R(NSN)R [R = Me (a), Et (b), $\left.{ }^{n} \operatorname{Pr}(\mathbf{c}),{ }^{n} \mathrm{Bu}(\mathbf{d})\right]$ react with cyclic bis(amino)stannylenes such as 1,3-di-tert-butyl-4,4-dimethyl-1,3,4,2 $\lambda^{2}$-diazasilastannetedine (2) or 1,3-di-tert-butyl-4,4,5,5-tetramethyl-1,3,4,5,2 $\lambda^{2}$-diazadisilastannolidine (3) in a 2:1 ratio to give the new spiro-tin(IV) compounds 5a-d, $\mathbf{6 b}$ and $\mathbf{6 c}$, built from the respective cyclic bis(amino)stannylene and a seven-membered ring in which the two sulfur diimide groups are coupled via a $\mathrm{N}-\mathrm{N}$ bond and across the tin atom. A 1:1 adduct $\mathbf{4}$ is proposed as an intermediate which is the final product $4 \mathbf{e}$ in the case of $\mathrm{R}={ }^{t} \mathrm{Bu}(\mathbf{1 e})$. The products were characterized by multinuclear magnetic resonance $\left({ }^{1} \mathrm{H},{ }^{13} \mathrm{C},{ }^{15} \mathrm{~N},{ }^{29} \mathrm{Si},{ }^{119} \mathrm{Sn} \mathrm{NMR}\right)$, and in the case of $\mathbf{5} \mathbf{c}$ the molecular structure was determined by single crystal X-ray structure analysis [monoclinic, space group $\left.\mathrm{C} 2 / c ; a=1504.1(3), b=1393.3(3), c=1688.6(3) \mathrm{pm} ; \beta=115.71(3)^{\circ}\right]$.

\section{Introduction}

Sulfur diimides are well known to form adducts with Lewis acids $[1,2]$ and to take part in redox reactions $[1,3]$. Therefore, tin(II) compounds should be suitable candidates to study the reactivity of sulfur diimides. It has been shown that bis(amino)stannylenes can behave both as Lewis acids $[4,5]$ or Lewis bases [6], and that they are readily converted to $\mathrm{Sn}$ (IV) derivatives by oxidative addition [7]. In continuing our studies on the properties and reactivity of sulfur diimides [3, 8] and bis(amino)stannylenes [9], we report here on the reactions of $\mathrm{N}, \mathrm{N}^{\prime}$-dialkylsulfur diimides 1 with the cyclic bis(amino)stannylenes $\mathbf{2}$ and $\mathbf{3}$.

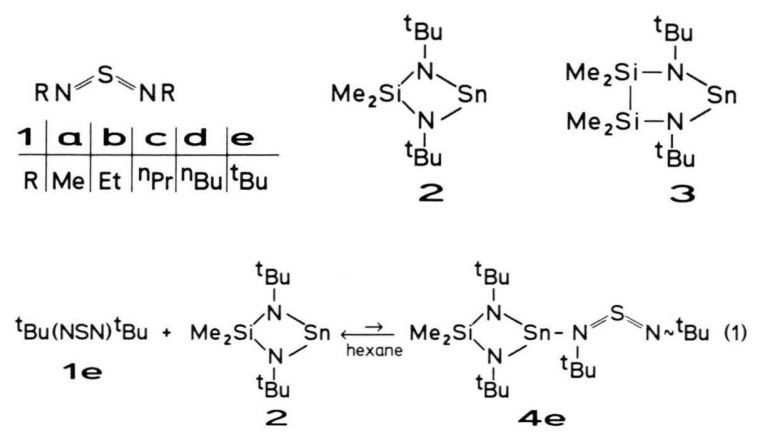

* Reprint requests to Prof. Dr. M. Herberhold or Prof. Dr. B. Wrackmeyer.

\section{Results and Discussion}

\section{Synthesis}

The starting materials 1 [10], 2 [11] and 3 [12] are readily obtained following literature procedures. Since $1 \mathrm{e}$ is the most stable and also the most conveniently accessible sulfur diimide in the series 1a-e, the reaction between $\mathbf{1 e}$ and $\mathbf{2}$ was studied first. The product $4 \mathbf{e}$ was obtained as an air- and moisturesensitive yellow solid [m. p. $57^{\circ} \mathrm{C}$, without decomposition; $c f$. 1e and $2\left(\mathrm{~m}\right.$. p. $\left.5^{\circ} \mathrm{C}\right)$ are liquids at room temperature], as the result of a 1:1 reaction eq. [(1)]. Compound $\mathbf{4 e}$ dissociates in solution almost completely into the sulfur diimide $1 \mathrm{e}$ and the stannylene $\mathbf{2}$. The interaction between $\mathbf{1 e}$ and $\mathbf{2}$ in hexane solution becomes evident only from colour changes (yellow to orange after addition of $\mathbf{2}$ to a hexane solution of $1 \mathrm{e}$ at $-78^{\circ} \mathrm{C}$ ) and from low temperature ${ }^{119} \mathrm{Sn}$ NMR spectra. After dissolving the solid adduct $\mathbf{4 e}$, the $\delta^{119} \mathrm{Sn}$ values at different temperatures are not identical with those of a solution of pure 2 [e.g., $4 \mathrm{e}: \delta^{119} \mathrm{Sn}\left(-55^{\circ} \mathrm{C}\right)=+517.2$ and 2: $\left.\delta^{119} \mathrm{Sn}\left(-55^{\circ} \mathrm{C}\right)=+560.3\right]$. Heating of the hexane solution to reflux for several hours does not induce further reactions.

Since it can be assumed that the apparently weak bonding between $\mathbf{1 e}$ and $\mathbf{2}$ is the result of steric hindrance, the sulfur diimides 1a-d were used. An 
Table I. ${ }^{13} \mathrm{C}$-, ${ }^{14 / 15} \mathrm{~N}$ - and ${ }^{119} \mathrm{Sn}$ NMR data ${ }^{[\mathrm{a}]}$ of the spiro-tin compounds $\mathbf{5}$ and $\mathbf{6}$.

\begin{tabular}{|c|c|c|c|c|c|c|c|c|c|c|}
\hline $\begin{array}{l}\text { Comp } \\
\text { No. }\end{array}$ & $\begin{array}{l}\text { ound } \\
\text { R }\end{array}$ & $\begin{array}{l}\delta^{13} \mathrm{C} \\
\mathrm{R}-\mathrm{N}-\mathrm{Sn}\end{array}$ & $\mathrm{R}-\mathrm{N}-\mathrm{N}$ & ${ }^{t} \mathrm{BuN}$ & $\mathrm{Me}_{2} \mathrm{Si}$ & $\begin{array}{l}\delta^{15} \mathrm{~N} \\
\mathrm{~N}-\mathrm{Sn}\end{array}$ & $\mathrm{N}-\mathrm{N}$ & $\mathrm{NSi}$ & $\delta^{29} \mathrm{Si}$ & $\delta^{119} \mathrm{Sn}$ \\
\hline $5 a$ & $\mathrm{Me}$ & $\begin{array}{l}47.5 \\
{[62.7]}\end{array}$ & $\begin{array}{l}47.0 \\
{[<1]}\end{array}$ & $\begin{array}{l}51.2,35.9 \\
{[19.6][31.6]}\end{array}$ & $\begin{array}{l}6.6 \\
{[n . \mathrm{m} .]}\end{array}$ & n. m. & n. m. & n. m. & 0.1 & -134.4 \\
\hline $5 b$ & Et & $\begin{array}{l}55.6,19.2 \\
{[55.6][<1]}\end{array}$ & $\begin{array}{l}53.4,13.5 \\
{[<1][<1]}\end{array}$ & $\begin{array}{l}51.4,35.9 \\
{[18.5][30.5]}\end{array}$ & $\begin{array}{l}6.6 \\
{[27.2]} \\
(58.3)\end{array}$ & $\begin{array}{l}-313.6 \\
{[20.1]}\end{array}$ & $\begin{array}{l}-247.1 \\
{[<1]}\end{array}$ & $\begin{array}{l}-292.5 \\
{[4.2]} \\
(15.1)\end{array}$ & -0.5 & -146.3 \\
\hline $5 c^{[b]}$ & ${ }^{n} \operatorname{Pr}$ & $\begin{array}{l}63.2,27.0 \\
{[52.3][4.9]}\end{array}$ & $\begin{array}{l}60.9,21.1 \\
{[<1][<1]}\end{array}$ & $\begin{array}{l}51.3,36.0 \\
{[18.5][29.4]}\end{array}$ & $\begin{array}{l}6.6 \\
{[27.3]} \\
(58.3)\end{array}$ & $\begin{array}{l}-316.5 \\
{[\mathrm{n} . \mathrm{m} .]}\end{array}$ & $\begin{array}{l}-245.3 \\
{[<1]}\end{array}$ & $\begin{array}{l}-292.4 \\
{[<1]} \\
(15.2)\end{array}$ & -0.5 & -146.5 \\
\hline $5 \mathbf{d}^{[\mathrm{c}]}$ & ${ }^{n} \mathrm{Bu}$ & $\begin{array}{l}61.2,36.2 \\
{[51.8][<1]}\end{array}$ & $\begin{array}{l}58.7,34.8 \\
{[<1][<1]}\end{array}$ & $\begin{array}{l}51.5,36.1 \\
{[18.5][29.3]}\end{array}$ & $\begin{array}{l}6.9 \\
{[\text { n. m.] }}\end{array}$ & $\begin{array}{l}-315.3 \\
{[\text { n. m.] }}\end{array}$ & $\begin{array}{l}-245.5 \\
{[<1]}\end{array}$ & $\begin{array}{l}-292.5 \\
{[<1]} \\
(15.6)\end{array}$ & -0.8 & -146.7 \\
\hline $6 b$ & Et & $\begin{array}{l}54.4,18.4 \\
{[58.2][<1]}\end{array}$ & $\begin{array}{l}52.8,13.4 \\
{[<1][<1]}\end{array}$ & $\begin{array}{l}56.6,35.2 \\
{[<1][24.2]}\end{array}$ & $\begin{array}{l}5.6,4.6 \\
{[16.9]}\end{array}$ & n. m. & n. $m$. & n. m. & $\begin{array}{l}-11.4 \\
{[69.8]}\end{array}$ & -113.8 \\
\hline $6 c^{[d]}$ & ${ }^{n} \operatorname{Pr}$ & $\begin{array}{l}62.7,27.1 \\
{[55.0][4.9]}\end{array}$ & $\begin{array}{l}52.8,13.4 \\
{[<1][<1]}\end{array}$ & $\begin{array}{l}56.6,35.2 \\
{[<1][24.0]}\end{array}$ & $\begin{array}{l}5.4,4.5 \\
{[16.9]}\end{array}$ & n. o. & $\begin{array}{l}-246.3 \\
{[<1]}\end{array}$ & $\begin{array}{l}-314.8 \\
{[43.3]} \\
(4.5,2.4)\end{array}$ & $\begin{array}{l}-10.9 \\
{[71.8]}\end{array}$ & -114.1 \\
\hline
\end{tabular}

[a] In $\mathrm{C}_{6} \mathrm{D}_{6}\left(\approx 10-20 \%, 25 \pm 1{ }^{\circ} \mathrm{C}\right)$; coupling constants $J\left({ }^{29} \mathrm{SiX}\right)$ and $J\left({ }^{119} \mathrm{SnX}\right)( \pm 0.5 \mathrm{~Hz})$ with $\mathrm{X}={ }^{13} \mathrm{C},{ }^{15} \mathrm{~N},{ }^{29} \mathrm{Si}$ are given in parentheses and square brackets, respectively; n. m. = not measured and n. o. = not observed; $[<1]$ or $[<3]$ means that the signal-to-noise ratio was in principle sufficient for measuring $J\left({ }^{119} \mathrm{SnX}\right)$ but the coupling constant was too small for accurate determination; [b] other $\delta^{13} \mathrm{C}$ values: $\delta=12.0,11.4(\mathrm{Me})$; [c] other $\delta^{13} \mathrm{C}$ values: $\delta=20.8,20.6$ $\left(\mathrm{CH}_{2}\right) ; 14.3,14.2(\mathrm{Me})$; [d] other $\delta^{13} \mathrm{C}$ values: $\delta=12.0,11.7(\mathrm{Me})$.

intense, red colour appeared immediately after addition of $\mathbf{2}$ to hexane solutions of the respective sulfur diimide 1 at $-78^{\circ}$. However, the colour was fading upon warming to room temperature. In order to obtain products with reproducible composition two equivalents of each sulfur diimide were required. After removing the solvent the moisturesensitive compounds 5a-d remained as colourless solids. Compounds $\mathbf{6} \mathbf{b}$ and $\mathbf{6 c}$ were obtained in the same way from the reactions between $\mathbf{3}$ and two equivalents of the sulfur diimides $\mathbf{1 b}$ and $\mathbf{1 c}$, respectively. Analytical data and ${ }^{1} \mathrm{H}$ NMR spectra of 5 and $\mathbf{6}$ prove that they consist of one equivalent of $\mathbf{2}$ or $\mathbf{3}$ and two equivalents of the respective sulfur diimide 1.

Even on the basis of a fairly complete set of ${ }^{1} \mathrm{H}$, ${ }^{13} \mathrm{C},{ }^{15} \mathrm{~N},{ }^{29} \mathrm{Si}$ and ${ }^{119} \mathrm{Sn}$ NMR data (see Table I and Experimental) for most of the compounds $\mathbf{5}$ and $\mathbf{6}$, it was not possible to assign their structure in solution with certainty. Although spiro-tin compounds with the structure A were potential candidates, this structure could be ruled out because of the $2: 1$ stoichiometry. A structure $\mathbf{B}$ for 2:1 adducts seemed possible, or a spiro-tin form $\mathbf{C}$. In $\mathbf{C}$, the $\mathrm{S}-\mathrm{S}$ bond could have been formed in the course of a redox reaction leading to $\operatorname{Sn}(\mathrm{IV})$. Finally, the result of the $\mathrm{X}$-ray crystal structure analysis of $\mathbf{5 c}$ (vide infra), together with the extensive set of NMR data (Table I), suggested that all compounds $\mathbf{5}$ and $\mathbf{6}$ should have the same type of the rather unexpected molecular structure where $\mathrm{Sn}$ (II) was oxidized to $\mathrm{Sn}$ (IV), two S(IV) were reduced to two S(II), and a N-N bond was formed by oxidation. One way to explain the formation of $\mathbf{5}$ and $\mathbf{6}$ is to consider an insertion of a sulfur diimide into the $\mathrm{Sn}-\mathrm{N}$ bond of the fourmembered SnNSN ring in A. On the other hand, an

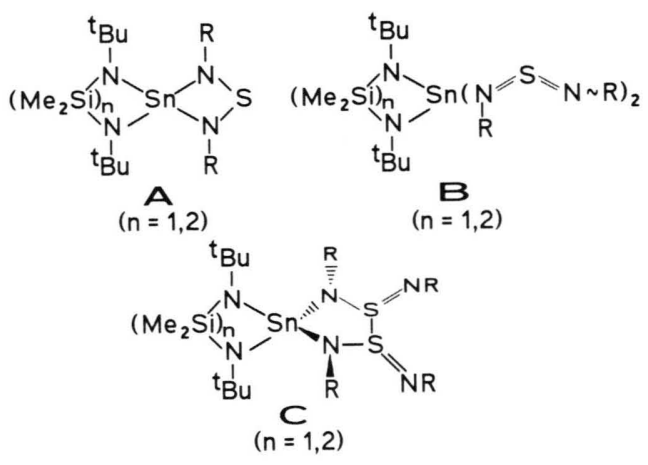


intramolecular redox reaction of the $2: 1$ adduct $\mathbf{B}$ could lead to $\mathbf{5}$ and $\mathbf{6}$, either directly or via another intermediate such as $\mathbf{C}$.

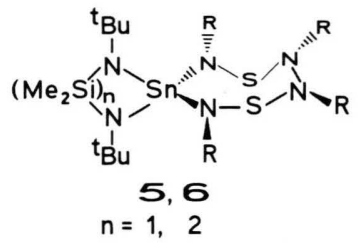

Since it is conceivable that potential intermediates possess structures like $\mathbf{4}$ and/or A - C, the reactions were monitored by ${ }^{119} \mathrm{Sn}$ NMR measurements, as shown in Fig. 1. In addition to the ${ }^{119} \mathrm{Sn}$ NMR signal for the final product, two other ${ }^{119} \mathrm{Sn}$ resonances close to $\delta^{119} \mathrm{Sn}=0$ were observed in some cases. For $\mathrm{R}={ }^{n} \mathrm{Pr}$, these signals could be detected only for a few minutes at room temperature. For smaller groups $\mathrm{R}$, the reactions appear to be complete already at $-50^{\circ} \mathrm{C}$. The $\delta^{119} \mathrm{Sn}$ values close to $\delta^{119} \mathrm{Sn}=0$ may represent $1: 1$ adducts $(\mathbf{4})$ or $2: 1$ adducts (B), but not the compounds with the structures $\mathbf{A}$ or $\mathbf{C}$, for which higher ${ }^{119}$ Sn nuclear shielding is to be expected (see $\delta^{119} \mathrm{Sn}$ values in Table I).

\section{$X$-Ray analysis of the spiro-tin compound $\mathbf{5 c}$}

Data relevant to the X-ray structure determination of $\mathbf{5 c}$ are given in Table II [13]. The molecular

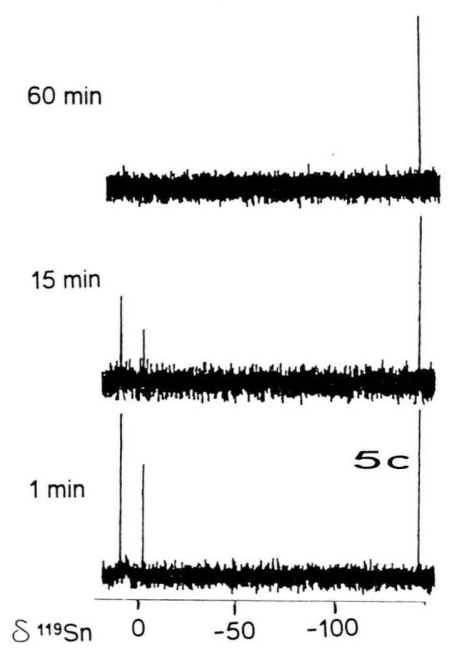

Fig. 1. $111.9 \mathrm{MHz}{ }^{119} \mathrm{Sn}\left\{{ }^{1} \mathrm{H}\right.$ inverse gated $\}$ NMR spectrum of a reaction solution $(\mathbf{1 c}+\mathbf{2}$ in a molar ratio of $2: 1$ in hexane), warmed to room temperature, after 1,15 and 60 minutes. The ${ }^{119} \mathrm{Sn}$ NMR signal of the final product $\mathbf{5 c}$ is already present, and the intensities of two other ${ }^{119} \mathrm{Sn}$ NMR signals $(\delta+8.8$ and -3.0$)$, assigned to intermediates such as $\mathbf{4}$ and/or $\mathbf{B}$, decrease fast.
Table II. Experimental data related to the single crystal $\mathrm{X}$-ray analysis of $\mathbf{5 c}$.

\begin{tabular}{|c|c|}
\hline Formula (molecular mass) & 611.6 \\
\hline Crystal; size [mm] & $\begin{array}{l}\text { Colourless, isometric; } \\
0.28 \times 0.25 \times 0.22\end{array}$ \\
\hline $\begin{array}{l}\text { Crystal system; } \\
\text { space group; } Z\end{array}$ & $\begin{array}{l}\text { Monoclinic; } \\
\text { C2/c; } 4\end{array}$ \\
\hline $\begin{array}{l}\text { Unit cell dimensions } \\
{[\mathrm{pm}] ;\left[^{\circ}\right]}\end{array}$ & $\begin{array}{l}a=1504.1(3), b=1393.3(3) \\
c=1157.1(3) ; \beta=115.71(3)\end{array}$ \\
\hline $\mathrm{V}\left[\AA^{3}\right]$ & $3188.5(11)$ \\
\hline $\begin{array}{l}\text { Absorption } \\
\text { coefficient }\left[\mathrm{mm}^{-1}\right]\end{array}$ & 0.989 \\
\hline Diffractometer & $\begin{array}{l}\text { Siemens P4 (graphite } \\
\text { monochromator) }\end{array}$ \\
\hline Radiation [pm] & $\mathrm{MoK}_{\alpha}, \lambda=71.073$ \\
\hline Temperature $[\mathrm{K}]$ & 173 \\
\hline $2 \Theta$-range & $2^{\circ}<2 \theta<55^{\circ}$ \\
\hline Scan type & $\omega$ \\
\hline Scan range $(\omega)$ & $1.2^{\circ}$ \\
\hline Measured reflections & 4430 \\
\hline $\begin{array}{l}\text { Independent/observed } \\
\text { reflections }\end{array}$ & $3526(\mathrm{~F}>0 \sigma(\mathrm{F}))$ \\
\hline Absorption correction & $\Psi$-Scans \\
\hline Min./max. transmission & $0.6209 / 0.6842$ \\
\hline Refined parameters & 144 \\
\hline Solution & Direct methods \\
\hline Weighting scheme & $w^{-1}=\sigma^{2}(\mathrm{~F})$ \\
\hline$R$-/wR-value & $0.0670 / 0.0395$ \\
\hline $\begin{array}{l}\text { Max./min. residual } \\
\text { electron density } \\
{\left[\mathrm{e} / \mathrm{pm}^{3}\right] \times 10^{-6}}\end{array}$ & $0.79 /-0.65$ \\
\hline
\end{tabular}

structure of $\mathbf{5 c}$ is shown in Fig.2, together with selected bond lengths and angles. The propyl groups linked to the hydrazine moiety are disordered. The two former sulfur diimide molecules are coupled via the $\mathrm{N}-\mathrm{N}$ bond and the tin atom, building a sevenmembered non-planar ring (see Fig. 3). $\mathrm{A} \mathrm{C}_{2}$ axis passes through the middle of the $\mathrm{N}-\mathrm{N}$ bond, the tin and the silicon atom. The sulfur atoms have nonbonding S ...S distances (349 pm). The structure of the planar four-membered SnNSiN-ring in $\mathbf{5 c}$ is retained with similar bond lengths and angles as in the monomer 2 [14]. The coordination sphere of the tin atom in $\mathbf{5 c}$ corresponds to a distorted tetrahedron with a small $\mathrm{N}(1)-\mathrm{Sn}-\mathrm{N}(1 \mathrm{a})\left[76.8(2)^{\circ}\right]$ and a larger endocyclic $\mathrm{N}(2)-\mathrm{Sn}-\mathrm{N}(2 \mathrm{a})$ bond angle [101.6(2) ${ }^{\circ}$ ] for the four- and the seven-membered ring, respectively. All four $\mathrm{Sn}-\mathrm{N}$ bond lengths are almost identical [203.4(4) and 203.3(4) pm], whereas the S$\mathrm{N}$ bond lengths are different $[\mathrm{S}-\mathrm{N}(2)=165.4$ and $\mathrm{S}-\mathrm{N}(3)=170.2(5) \mathrm{pm}]$, both being significantly

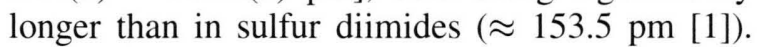


The different $\mathrm{S}-\mathrm{N}$ bond lengths fit to the trigonal planar surrounding of $\mathrm{N}(2)$ [sum of bond angles at $\left.\mathrm{N}(2)=359.8(8)^{\circ}\right]$ and the pyramidal surrounding of $\mathrm{N}(3)$ [sum of bond angles at $\mathrm{N}(3)=336.5(8)^{\circ}$ ].

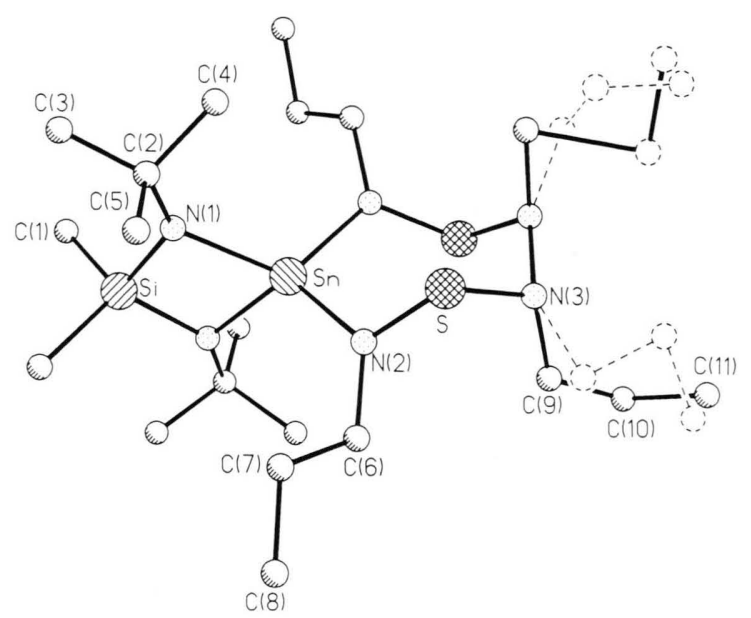

Fig. 2. Molecular structure of the spiro-tin compound 5c. Selected bond lengths [pm] and angles $\left[^{\circ}\right]$ : $\mathrm{Sn}-\mathrm{N}(2)$ 203.3(4), $\mathrm{Sn}-\mathrm{N}(1)$ 203.4(4), S-N(2) 165.4(4), S-N(3) 170.2(5), N(3)-N(3a) 149.4 (16), Si$\mathrm{N}(1) 174,1$ (4); N(1)-Si-N(1a) 93.1(2), N(1)-Sn-N(1a) 76.8(2), Si-N(1)-Sn 95.0(2), N(2)-Sn-N(2a) 101.6(2), $\mathrm{Sn}-\mathrm{N}(2)-\mathrm{S} 119.0(2), \mathrm{N}(2)-\mathrm{S}-\mathrm{N}(3)$ 110.6(2), S-N(3)$\mathrm{N}(3 \mathrm{a}) 117.2$ (6).

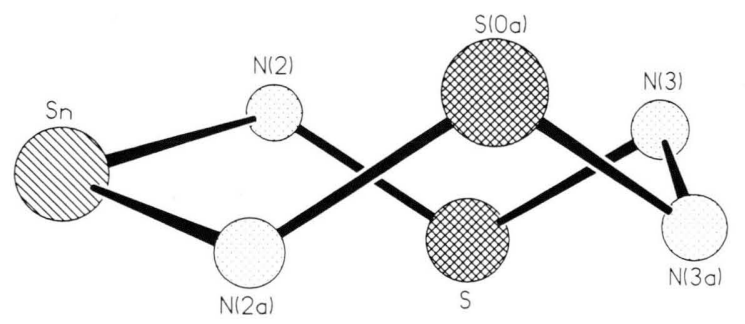

Fig. 3. Section of the molecular structure of $\mathbf{5}$, showing the conformation of the seven-membered SnNSNNSN ring.

\section{NMR spectroscopic results}

${ }^{1} \mathrm{H}$ and ${ }^{13} \mathrm{CNMR}$. - The assignment of the ${ }^{1} \mathrm{H}$ and ${ }^{13} \mathrm{C}$ NMR signals is based on $2 \mathrm{D}{ }^{13} \mathrm{C} /{ }^{1} \mathrm{H}$ heteronuclear shift correlations, together with the detection of satellites due to $J\left({ }^{119} \mathrm{Sn}^{1} \mathrm{H}\right)$ and $J\left({ }^{119} \mathrm{Sn}^{13} \mathrm{C}\right)$. If the symmetry of the solid-state molecular structure $\left(\mathrm{C}_{2}\right.$ axis passing through the middle of the $\mathrm{N}-\mathrm{N}$ bond, the tin and the silicon atom in $\mathbf{5 c}$ ) is retained in solution, and if a comparable structure is assumed for compounds 6 (the $\mathrm{C}_{2}$ axis would then pass through the middle of the $\mathrm{Si}-\mathrm{Si}$ bond in $\mathbf{6}$ ), one expects the following prominent features in the ${ }^{1} \mathrm{H}$ NMR spectra [15]: (i) In the case of $\mathbf{5}$, there should be separate signals for the diastereotopic protons of the $\mathrm{CH}_{2}$ groups, but only a single ${ }^{1} \mathrm{H}$ resonance for the $\mathrm{SiMe}_{2}$ protons; (ii) in the case of $\mathbf{6}$, the analogous pattern is expected for the ${ }^{1} \mathrm{H}\left(\mathrm{CH}_{2}\right)$ signals, but the $\mathrm{SiMe}_{2}$ protons should give two ${ }^{1} \mathrm{H}$ NMR signals. This is actually observed for all compounds studied (see Fig. 4 for $\mathbf{6 c}$ ), and it is confirmed by the ${ }^{13} \mathrm{C}$ NMR data (one ${ }^{13} \mathrm{C}$ NMR signal for the $\mathrm{SiMe}_{2}$ group in $\mathbf{5}$ and two ${ }^{13} \mathrm{C}(\mathrm{SiMe})$ resonances in $\left.\mathbf{6}\right)$.

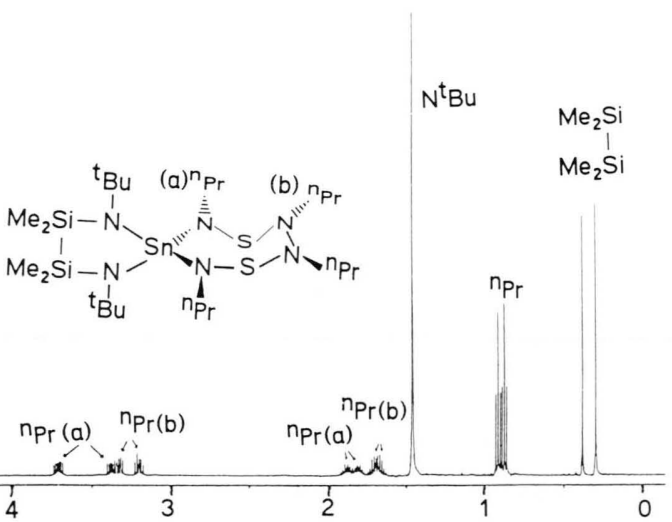

Fig. 4. $500.13 \mathrm{MHz}{ }^{1} \mathrm{H}$ NMR spectrum of $\mathbf{6 c}$, showing that the ${ }^{1} \mathrm{H}$ nuclei attached to prochiral centres become diastereotopic.

${ }^{15} N$ NMR. - The ${ }^{15} \mathrm{~N}$ NMR measurements of $\mathbf{5}$ and $\mathbf{6}$ at natural abundance were carried out within reasonable time when it proved possible to apply polarization transfer techniques, e. g. INEPT [16], based on long-range coupling constants ${ }^{n} J\left({ }^{15} \mathrm{~N}^{1} \mathrm{H}\right)$. This was straightforward in the case of ${ }^{t} \mathrm{BuN}$ groups, but for other RN groups, some of the measurements were rather time-consuming, in particular for the detection of ${ }^{117 / 119} \mathrm{Sn}$ or ${ }^{29} \mathrm{Si}$ satellites. This explains why some ${ }^{15} \mathrm{~N}$ NMR data are missing in Table I. The proposed structures for 5 and $\mathbf{6}$ require three ${ }^{15} \mathrm{~N}$ resonance signals, all shifted to lower frequencies with respect to sulfur diimides $[8,10 \mathrm{c}]$. The ${ }^{15} \mathrm{~N}$ nuclei of the hydrazine moiety should be deshielded as compared to the other nitrogen atoms, and satellites due to coupling with ${ }^{117 / 119} \mathrm{Sn}$ or ${ }^{29} \mathrm{Si}$ are likely to be absent. Of the two other ${ }^{15} \mathrm{~N}$ signals, one should possess both ${ }^{117 / 119} \mathrm{Sn}$ and ${ }^{29} \mathrm{Si}$ satellites, representing 
the nitrogen atoms in the four- or five-membered ring, and the other should be accompanied only by ${ }^{117 / 119} \mathrm{Sn}$ satellites since it belongs to the sevenmembered ring. This has indeed been observed for several examples (see Table I), and a representative ${ }^{15} \mathrm{~N}$ NMR spectrum is shown in Fig. 5.

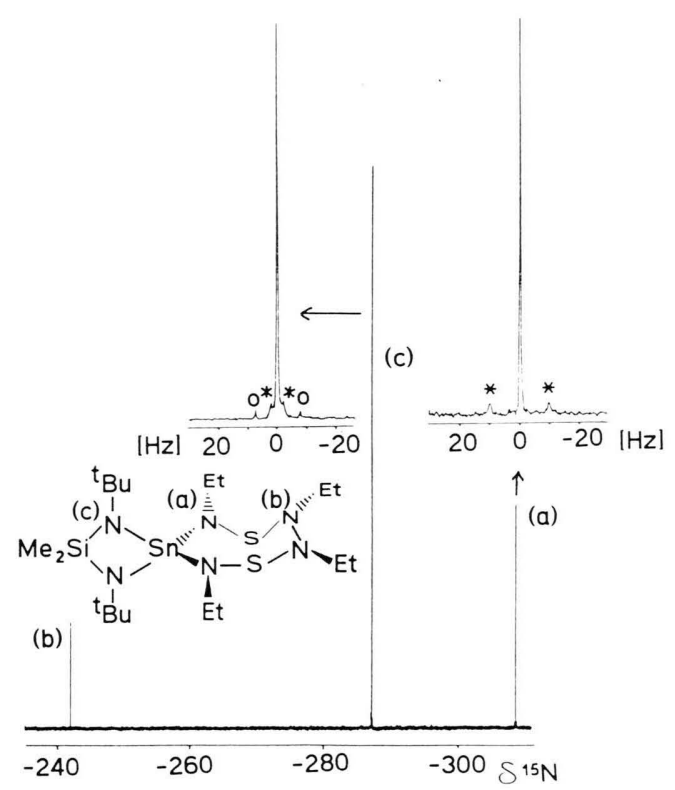

Fig. 5. $50.7 \mathrm{MHz}{ }^{15} \mathrm{~N}$ NMR spectrum of $\mathbf{5 b}$ in $\mathrm{C}_{6} \mathrm{D}_{6}$ (ca. $15 \%)$ at $25 \pm 1{ }^{\circ} \mathrm{C}$ [recorded by using the refocused INEPT pulse sequence, optimized for $\left.\left.{ }^{3} J\left({ }^{15} \mathrm{~N}^{1} \mathrm{H}\right)=3.4 \mathrm{~Hz}\right)\right]$. The deviation from $1: 1: 1$ intensity is due to differing response to polarization transfer of the three types of ${ }^{15} \mathrm{~N}$ nuclei. Expanded sections show the ${ }^{15} \mathrm{~N}$ NMR signals with ${ }^{117 / 119} \mathrm{Sn}$ (marked by asterisks) and ${ }^{29} \mathrm{Si}$ satellites (marked by open circles).

In general the sign of ${ }^{1} J\left({ }^{119} \mathrm{Sn}^{15} \mathrm{~N}\right)$ is negative in trialkyl(amino)tin(IV) compounds, passes through zero in bis(amino)tin(IV) compounds and becomes positive in tris- and tetrakis(amino)tin(IV) compounds [17, 18]. However, in the case of four-membered rings, such as in compounds $\mathbf{5}$, $J\left({ }^{119} \mathrm{Sn}^{15} \mathrm{~N}\right)$ is small and may be of either sign. Because of the smaller polarizability of the $\mathrm{Si}-\mathrm{N}$ bond (as compared to $\mathrm{Sn}-\mathrm{N}$ ) the ${ }^{1} J\left({ }^{29} \mathrm{Si}^{15} \mathrm{~N}\right.$ ) values for 5 are in the expected range [17]. Small values ${ }^{1} J\left({ }^{29} \mathrm{Si}^{15} \mathrm{~N}\right)$, as found for $\mathbf{6 c}$, are typical of 1,2 bis(amino)-tetramethyl-disilanes [19], and in these cases ${ }^{29} \mathrm{Si}$ satellites according to ${ }^{2} J\left({ }^{29} \mathrm{Si}^{15} \mathrm{~N}\right)$ are also frequently observed.
${ }^{29} \mathrm{Si}$ and ${ }^{119} \mathrm{Sn} N M R$. - The $\delta^{29} \mathrm{Si}$ values for $\mathbf{5}$ and 6 are found in the typical range for such compounds [20]. As observed for other four-membered SiNSnNrings [21], the magnitude of the geminal coupling constant ${ }^{2} J\left({ }^{119} \mathrm{Sn}^{29} \mathrm{Si}\right)$ is very small in $\mathbf{5}$. In the case of compound $\mathbf{6}$, there are two different coupling pathways across two and three bonds in the five-membered ring. The three-bond contribution dominates and gives rise to fairly large values ${ }^{2} J\left({ }^{119} \mathrm{Sn}^{29} \mathrm{Si}\right)(\mathbf{6 b}: 69.8 \mathrm{~Hz}$; 6c: $71.8 \mathrm{~Hz})$.

The $\delta^{119} \mathrm{Sn}$ values of $\mathbf{5}$ and $\mathbf{6}$ are typical of tetrakis(amino)tin compounds [22]. The reduced ${ }^{119} \mathrm{Sn}$ nuclear shielding in $\mathbf{6}$ as compared to $\mathbf{5}$ is noteworthy. It appears to be a general phenomenon that ${ }^{119}$ Sn nuclear deshielding is observed if the tin atom is part of a five-membered ring [22, 23], irrespective of the nature of the other ring atoms.

The consistent set of NMR data for the spirotin compounds 5 and $\mathbf{6}$ in solution indicates that the main features of the molecular structure, as determined for $\mathbf{5 c}$ in the solid state, are retained in solution. So far, the sensitivity of the adduct $4 \mathbf{e}$ and also of the compounds $\mathbf{5}$ and $\mathbf{6}$ has prevented the application of solid-state NMR for comparing liquidand solid-state NMR data.

\section{Experimental}

All synthetic work and handling of samples was routinely carried out in an inert atmosphere $\left(\mathrm{Ar}\right.$ or $\left.\mathrm{N}_{2}\right)$. The starting materials were either commercial products or prepared as described earlier for $\mathbf{1}$ [10], 2 [11] and 3 [12].

NMR measurements (in $5 \mathrm{~mm}$ tubes at $25 \pm 1{ }^{\circ} \mathrm{C}$, if not mentioned otherwise; see also Table I) were performed using Jeol FX 90Q, Bruker AC 300 and Bruker AM 500 instruments, all equipped with variable temperature and multinuclear units: ${ }^{1} \mathrm{H} /{ }^{13} \mathrm{C}$ NMR $[\delta$ values relative to $\left.\mathrm{Me}_{4} \mathrm{Si}: \delta^{1} \mathrm{H}\left(\mathrm{C}_{6} \mathrm{D}_{5} \mathrm{H}\right)=7.15 ; \delta^{13} \mathrm{C}\left(\mathrm{C}_{6} \mathrm{D}_{6}\right)=128.0\right]$; ${ }^{15} \mathrm{~N}$ NMR [external reference: neat $\mathrm{MeNO}_{2}, \Xi\left({ }^{15} \mathrm{~N}\right)=$ $10.136767 \mathrm{MHz}$ ]; ${ }^{29} \mathrm{Si}$ NMR [external reference: $\mathrm{Me}_{4} \mathrm{Si}$, $\left.\Xi\left({ }^{29} \mathrm{Si}\right)=19.867184 \mathrm{MHz}\right],{ }^{119} \mathrm{Sn}$ NMR [external reference: $\left.\mathrm{Me}_{4} \mathrm{Sn} ; \Xi\left({ }^{119} \mathrm{Sn}\right)=37.290665 \mathrm{MHz}\right]$.

\section{1:1 Adduct (4e) of 1,3-di-tert-butyl-4,4-dimethyl-1,3,4,2 $\lambda^{2}$-diazasilastannetidine (2) and $N, N^{\prime}$-di-tert-butyl sulfur diimide (1e)}

A solution of $0.87 \mathrm{~g}(5 \mathrm{mmol})$ of $1 \mathrm{e}$ in $20 \mathrm{ml}$ of hexane is cooled to $-78^{\circ} \mathrm{C}$, and a solution of $1.6 \mathrm{~g}(5 \mathrm{mmol})$ of $2 \mathrm{in} 10 \mathrm{ml}$ of hexane is added dropwise. The yellow colour changes immediately to orange. After warming to room temperature and removing of the solvent, $2.47 \mathrm{~g}$ of 
4e remains as a yellow solid (m. p. $57{ }^{\circ} \mathrm{C}$ without decomposition). Compound $\mathbf{4 e}$ dissolves readily in hexane, toluene or benzene where it dissociates into $\mathbf{1 e}$ and $\mathbf{2}$. The adduct $\mathbf{4 e}$ can be recovered completely if the solvents are removed.

\section{5,7,8,10-Tetraalkyl-1,3-di-tert-butyl-2,2-dimethyl- $6 \sigma^{2} \lambda^{2}, 9 \sigma^{2} \lambda^{2}$-dithia-1,3,5,7,8,10-hexaza-2-sila-4- stannaspiro[3,6]decanes (5a-d)}

A solution of $10 \mathrm{mmol}$ of the sulfur diimide 1 in $50 \mathrm{ml}$ of hexane is cooled to $-78^{\circ} \mathrm{C}$ and a solution of $1.6 \mathrm{~g}(5 \mathrm{mmol})$ of the stannylene $2 \mathrm{in} 30 \mathrm{ml}$ of hexane is added dropwise. An intense red colour develops immediately. Upon warming to room temperature, the solutions become colourless, and stirring is continued for further $24 \mathrm{~h}$ before the solvent is removed in vacuo. The residues are almost colourless solids which are recrystallized from a small amount $(\approx 5 \mathrm{ml})$ of hexane or pentane at $-78^{\circ} \mathrm{C}$. This process has to be repeated several times in order to get pure, colourless and crystalline material (yield: $22-25 \%)$.

5a: Dec. $>50^{\circ} \mathrm{C} .-{ }^{1} \mathrm{H}$ NMR $\left(\mathrm{C}_{6} \mathrm{D}_{6} ; 300 \mathrm{MHz}\right): \delta^{1} \mathrm{H}$ $\left[J\left({ }^{119} \mathrm{Sn}^{1} \mathrm{H}\right)\right]=0.30 \mathrm{~s}, 6 \mathrm{H}, \mathrm{SiMe}_{2} ; 1.15 \mathrm{~s}, 18 \mathrm{H}, \mathrm{N}^{t} \mathrm{Bu} ; 2.94$ s, 6H, NNMe; 3.24 [43.8] s, 6H, SnNMe.

5b: Dec. $>60^{\circ} \mathrm{C} .-{ }^{1} \mathrm{H}$ NMR $\left(\mathrm{C}_{6} \mathrm{D}_{6} ; 300 \mathrm{MHz}\right): \delta^{1} \mathrm{H}=$ $0.37 \mathrm{~s}, 6 \mathrm{H}, \mathrm{SiMe}_{2} ; 1.24 \mathrm{~s}, 18 \mathrm{H}, \mathrm{N}^{t} \mathrm{Bu} ; 3.31 \mathrm{~m}, 2 \mathrm{H}, 3.10$ m, $2 \mathrm{H}, 1.14 \mathrm{t}, 6 \mathrm{H}, \mathrm{NNEt} ; 3.72 \mathrm{~m}, 2 \mathrm{H}, 3.39 \mathrm{~m}, 2 \mathrm{H}, 1.36 \mathrm{t}$, $6 \mathrm{H}, \mathrm{SnNEt}$.

5c: Dec. $>60^{\circ} \mathrm{C} .{ }^{1} \mathrm{H}$ NMR $\left(\mathrm{C}_{6} \mathrm{D}_{6} ; 500 \mathrm{MHz}\right): \delta^{1} \mathrm{H}$ $=0.27 \mathrm{~s}, 6 \mathrm{H}, \mathrm{SiMe}_{2} ; 1.17 \mathrm{~s}, 18 \mathrm{H}, \mathrm{N}^{t} \mathrm{Bu} ; 3.26 \mathrm{~m}, 2 \mathrm{H}$,
$3.16 \mathrm{~m}, 2 \mathrm{H}, 1.60 \mathrm{~m}, 4 \mathrm{H}, 0.84 \mathrm{t}, 6 \mathrm{H}, \mathrm{NN}^{n} \mathrm{Pr} ; 3.73 \mathrm{~m}, 2 \mathrm{H}$ $3.40 \mathrm{~m}, 2 \mathrm{H}, 1.77 \mathrm{~m}, 4 \mathrm{H}, 0.89 \mathrm{t}, 6 \mathrm{H}, \mathrm{SnN}^{n} \mathrm{Pr}$.

$\mathrm{C}_{22} \mathrm{H}_{52} \mathrm{~N}_{6} \mathrm{~S}_{2} \mathrm{SiSn}(611.60)$

Calcd C 43.21 H 8.57 N $13.74 \%$,

Found C $42.80 \mathrm{H} 8.48 \mathrm{~N} 13.50 \%$.

5d: Dec. $>60^{\circ} \mathrm{C} .-{ }^{1} \mathrm{H}$ NMR $\left(\mathrm{C}_{6} \mathrm{D}_{6} ; 300 \mathrm{MHz}\right): \delta^{1} \mathrm{H}=$ $0.23 \mathrm{~s}, 6 \mathrm{H}, \mathrm{SiMe}_{2} ; 1.14 \mathrm{~s}, 18 \mathrm{H}, \mathrm{N}^{t} \mathrm{Bu} ; 3.19 \mathrm{~m}, 2 \mathrm{H}, 3.15$ $\mathrm{m}, 2 \mathrm{H}, 1.45 \mathrm{~m}, 4 \mathrm{H}, 1.60 \mathrm{~m}, 4 \mathrm{H}, 0.84 \mathrm{t}, 6 \mathrm{H}, \mathrm{NN}^{n} \mathrm{Bu} ; 3.71$ $\mathrm{m}, 2 \mathrm{H}, 3.31 \mathrm{~m}, 2 \mathrm{H}, 1.68 \mathrm{~m}, 4 \mathrm{H}, 1.23 \mathrm{~m}, 4 \mathrm{H}, 0.85 \mathrm{t}, 6 \mathrm{H}$, $\mathrm{SnN}^{n} \mathrm{Bu}$.

The compounds $\mathbf{6 b}$ and $\mathbf{6 c}$ were obtained in the same way as described for $\mathbf{5 a - d .}$

6b: Dec. $>70^{\circ} \mathrm{C} .-{ }^{1} \mathrm{H}$ NMR $\left(\mathrm{C}_{6} \mathrm{D}_{6} ; 300 \mathrm{MHz}\right): \delta^{1} \mathrm{H}=$ $0.34 \mathrm{~s}, 6 \mathrm{H}, 0.25 \mathrm{~s}, 6 \mathrm{H}, \mathrm{Si}_{2} \mathrm{Me}_{4} ; 1.37 \mathrm{~s}, 18 \mathrm{H}, \mathrm{N}^{t} \mathrm{Bu} ; 3.30$ $\mathrm{m}, 2 \mathrm{H}, 3.16 \mathrm{~m}, 2 \mathrm{H}, 1.01 \mathrm{t}, 6 \mathrm{H}, \mathrm{NNEt} ; 3.69 \mathrm{~m}, 2 \mathrm{H}, 3.36$ $\mathrm{m}, 2 \mathrm{H}, 1.09 \mathrm{t}, 6 \mathrm{H}$, SnNEt.

6c: Dec. $>70^{\circ} \mathrm{C}$. $-{ }^{1} \mathrm{H}$ NMR $\left(\mathrm{C}_{6} \mathrm{D}_{6} ; 500 \mathrm{MHz}\right.$, see Figure 4): $\delta^{1} \mathrm{H}=0.39 \mathrm{~s}, 6 \mathrm{H}, 0.31 \mathrm{~s}, 6 \mathrm{H}, \mathrm{Si}_{2} \mathrm{Me}_{4} ; 3.35$ $\mathrm{m}, 2 \mathrm{H}, 3.28 \mathrm{~m}, 2 \mathrm{H}, 1.70 \mathrm{~m}, 4 \mathrm{H}, 0.89 \mathrm{t}, 6 \mathrm{H}, \mathrm{NN}^{n} \mathrm{Pr} ; 3.75$ m, 2H, $3.40 \mathrm{~m}, 2 \mathrm{H}, 1.78 \mathrm{~m}, 2 \mathrm{H}, 1.72 \mathrm{~m}, 2 \mathrm{H}, 0.93 \mathrm{t}, 6 \mathrm{H}$, $\mathrm{SnN}^{n} \mathrm{Pr}$

$\mathrm{C}_{24} \mathrm{H}_{58} \mathrm{~N}_{6} \mathrm{~S}_{2} \mathrm{Si}_{2} \mathrm{Sn}(669.75)$

Calcd C $43.04 \mathrm{H} 8.73 \mathrm{~N} 12.54 \%$,

Found C 42.84 H 8.62 N 12.30\%.

\section{Acknowledgement}

Support of this work by the Deutsche Forschungsgemeinschaft and the Fonds der Chemischen Industrie is gratefully acknowledged.
[1] a) R. Bussas, G. Kresze, H. Münsterer, A. Schwöbel, Sulfur Rep. 2, 215-378 (1983);

b) G. Kresze, W. Wucherpfennig, Angew. Chem. 79, 109 (1967); Angew. Chem., Int. Ed. Engl. 6, 149 (1967).

[2] H. W. Roesky, H.-G. Schmidt, M. Noltemeyer, G. M. Sheldrick, Chem. Ber. 116, 1411 (1983).

[3] a) M. Herberhold, S. M. Frank, B. Wrackmeyer, A. Simon, H. Borrmann, Chem. Ber. 123, 75 (1990); b) B. Wrackmeyer, S. M. Frank, M. Herberhold, A. Simon, H. Borrmann, J. Chem. Soc. Dalton Trans. 2607 (1991);

c) M. Herberhold, S. Gerstmann, W. Milius, B. Wrackmeyer, Z. Naturforsch. 48b, 249 (1993); d) C. Habben, A. Meller, M. Noltemeyer, G. M. Sheldrick, J. Organomet. Chem. 288, 1 (1985);

e) C. Habben, A. Meller, S. Pusch, Z. Naturforsch. 43b, 959 (1988);

f) C. Habben, A. Meller, Chem. Ber. 119, 9 (1986).

[4] a) M. Veith, M. Grosser, Z. Naturforsch. 37b, 1375 (1982);

b) M. Veith, V. Huch, J. Organomet. Chem. 293, 161 (1985).

[5] M. Veith, Angew. Chem. 99, 1 (1987); Angew. Chem., Int. Ed. Engl. 26, 1 (1987).

[6] a) P. B. Hitchcock, M. F. L. Lappert, M. C. Misra, J. Chem. Soc. Chem. Commun. 863 (1985);

b) M. Veith, H. Lange, H. Brauer, R. Bachmann, J. Organomet. Chem. 216, 377 (1981). 
[7] a) M. F. Lappert, Rev. Silicon, Germanium, Tin and Lead Compds. 9, 130 (1986);

b) M. F. Lappert, P. P. Power, J. Chem. Soc. Dalton Trans. 51 (1985);

c) R. W. Chorley, P. B. Hitchcock, M. F. Lappert, J. Chem. Soc. Chem. Commun. 525 (1992);

d) M. Veith, O. Recktenwald, Z. Anorg. Allg. Chem. 459, 208 (1979).

[8] a) B. Wrackmeyer, K. Schamel, K. Guldner, M. Herberhold, Z. Naturforsch. 42b, 703 (1987);

b) M. Herberhold, S. M. Frank, B. Wrackmeyer, Z. Naturforsch. 43b, 985 (1988);

c) B. Wrackmeyer, S. M. Frank, M. Herberhold, A. Simon, H. Borrmann, Chem. Ber. 124, 691 (1991); d) M. Herberhold, S. M. Frank, B. Wrackmeyer, J. Organomet. Chem. 410, 159 (1991);

e) M. Herberhold, C. Köhler, B. Wrackmeyer, Phosphorus, Sulfur and Silicon 71, 75 (1992);

f) B. Wrackmeyer, Ē. Kupče, S. M. Frank, S. Gerstmann, M. Herberhold, Phosphorus, Sulfur and Silicon 69, 179 (1992);

g) B. Wrackmeyer, S. Gerstmann, M. Herberhold, Magn. Reson. Chem. 31, 499 (1993);

h) M. Herberhold, S. Gerstmann, W. Milius, B. Wrackmeyer, Z. Naturforsch. 48b, 1041 (1993); i) M. Herberhold, S. Gerstmann, B. Wrackmeyer, H. Borrmann, J. Chem. Soc. Dalton Trans. 633 (1994); j) B. Wrackmeyer, C. Köhler, W. Milius, M. Herberhold, Phosphorus, Sulfur and Silicon 89, 151 (1994); k) B. Wrackmeyer, S. Gerstmann, M. Herberhold, G. A. Webb, H. Kurosu, Magn. Reson. Chem. 32, 492 (1994);

l) B. Wrackmeyer, C. Köhler, W. Milius, M. Herberhold, Inorg. Chim. Acta 231, 249 (1995).

[9] a) B. Wrackmeyer, J. Magn. Reson. 61, 536 (1985); b) C. Stader, B. Wrackmeyer, J. Organomet. Chem. 321, C1 (1987);

c) C. Stader, B. Wrackmeyer, J. Magn. Reson. 72, 544 (1987);

d) C. Stader, B. Wrackmeyer, Z. Naturforsch. 42b, 1515 (1987);

e) B. Wrackmeyer, C. Stader, K. Horchler, J. Magn. Reson. 83, 601 (1989);

f) B. Wrackmeyer, K. Horchler, H. Zhou, Spectrochim. Acta 46A, 809 (1990); g) B. Wrackmeyer, C. Stader, K. Horchler, H. Zhou, D. Schlosser, Inorg. Chim. Acta 176, 205 (1990).

[10] a) R. Appel, J. Kohnke, Chem. Ber. 103, 2152 (1970);

b) D. H. Clemens, A. J. Bell, J. L. O'Brien, Tetrahedron Lett. 20, 1487 (1965);

c) B. Wrackmeyer, C. Köhler, M. Herberhold, Magn. Reson. Chem. 31, 987 (1993).

[11] M. Veith, Angew. Chem. 87, 287 (1975); Angew. Chem., Int. Ed. Engl. 14, 263 (1975).

[12] K. Horchler, C. Stader, B. Wrackmeyer, Inorg. Chim. Acta 117, L39 (1986).

[13] Further details of the crystal structure analysis are available on request from the Fachinformationszentrum Karlsruhe, GmbH, D-76344 Eggenstein-Leopoldshafen (FRG), on quoting the depository number CSD-401864.

[14] M. Veith, Z. Naturforsch. 33b, 7 (1978).

[15] W. B. Jennings, Chem. Rev. 75, 307 (1975).

[16] a) G. A. Morris, R. Freeman, J. Am. Chem. Soc. 101, 760 (1979);

b) D. P. Burum, R. R. Ernst, J. Magn. Reson. 39, 163 (1980);

c) G. A. Morris, J. Magn. Reson. 41, 185 (1980).

[17] B. Wrackmeyer, E. Kupče, in Topics of Physical Organometallic Chemistry, M. Gielen (ed.): Vol. 4, pp. 289-352, Freund Publishing House, Tel Aviv, (1992).

[18] M. Witanowski, L. Stefaniak, G. A. Webb, Annu. Rep. NMR Spectrosc. 18, 1 (1986).

[19] B. Wrackmeyer, C. Stader, H. Zhou, Spectrochim. Acta 45A, 1101 (1989).

[20] E. Kupče and E. Lukevics, in Isotopes in the Physical and Biomedical Science, E. Buncel, J. R. Jones (eds.): Vol. 2, pp. 213-295, Elsevier, Amsterdam (1991), and references cited therein.

[21] H. Zhou, Dissertation, Universität Bayreuth (1991).

[22] B. Wrackmeyer, Annu. Rep. NMR Spectrosc. 16, 73-185 (1985).

[23] a) J. D. Kennedy, W. McFarlane, G. S. Pyne, J. Chem. Soc. Dalton Trans. 2332 (1977);

b) J. D. Kennedy, W. McFarlane, G. S. Pyne, Bull. Soc. Chim. Belg. 84, 289 (1975);

c) B. Wrackmeyer, Rev. Silicon, Germanium, Tin, Lead Compds. 6, 75 (1982). 